\title{
Cellular magnesium levels and the use of penicillamine in the treatment of Huntington's chorea
}

\author{
M. T. HASLAM \\ From St. Nicholas Hospital, Gosforth, Newcastle upon Tyne
}

The possibility that Huntington's chorea might be due to a genetically determined biochemical derangement has been raised on a number of occasions. In 1963 , Kenyon and Hardy suggested that abnormalities of magnesium metabolism might account for some of the features of Huntington's chorea and in a group of patients investigated the cellular magnesium levels using the Szvenk-Fekete titration method and a modification of the method of Baron and Bell (1957). They found raised intracellular levels of magnesium and calcium compared with a control group. However Bruyn, Mink, and Caljé in 1965 reviewed the literature on this subject. They conducted tests on the magnesium levels in 35 patients with Huntington's chorea using a modification of Mann and Yoe's (1956) method, and found that the levels were all within normal limits.

Nielsen and Butt in 1955, on the basis that dimercaprol (B.A.L.), a chelating agent, was of use in the treatment of Wilson's disease, tried its effect on other diseases of the basal ganglia. They treated two patients with Huntington's chorea with B.A.L. for 12 and 14 months respectively and found 'definite clinical improvement'. Because of the unsuitability of B.A.L. for long-term use (intramuscular injections into the buttocks) this treatment had to be abandoned.

There are now chelating agents available which can be given orally with success to patients with Wilson's disease. The author can find no reference to a trial of chelating agents in the treatment of Huntington's chorea other than that of Nielsen and Butt (1955). The following paper describes a trial of penicillamine in patients with Huntington's chorea, carried out at St. Nicholas Hospital over a six-month period.

Of the chelating agents now available for oral use penicillamine seemed to be the most suitable, on the grounds that it had been successfully used in the long-term treatment of Wilson's disease; in reactivating impaired thiol-dependent enzyme systems in cystinosis; and in chloropromazine melanosis Penicillamine was known to sequestrate magnesium in vitro.

\section{SELECTION OF PATIENTS}

Ten patients with Huntington's chorea with clear family histories were taken and compared with a random group of 10 other patients from the same wards, matched for age and sex. Blood samples were taken and the plasma magnesium, whole blood, and red cell magnesium levels obtained, using the method of atomic absorption spectrophotometry with a strontium salt as a spectroscopic buffer, as developed in the Department of Biochemistry at Newcastle by Mr. C. D. Pendlerton.

Two patients were then selected for treatment with oral penicillamine at a dose of $1,500 \mathrm{mg}$. daily (as suggested by Dr. W. H. Lyle of Dista Products Ltd.). These patients were chosen because in addition to a clear-cut family history of the disease they were at a stage where choreiform movements were marked, but there was no evidence of dementia. The two cases are described below as they presented before the start of the trial.

CASE 1 T.L., a man aged 27, was admitted on 6 August 1964. The father died of Huntington's chorea in 1955, and the patient had three sibs, so far showing no signs of the disease. The patient was married, with two daughters. Personality change was first noted in 1962, when the patient became morose with outbursts of temper and occasional blackouts. Choreiform movements gradually developed over about seven years. Now he shows slurred speech, and his gait is very poor. He needs assistance to go upstairs, and cannot feed himself or shave. He has lost 2 stones in weight since the disease was manifest. He is being treated with Epanutin gr. $1 \frac{1}{2}$ t.d.s. Benuride $200 \mathrm{mg}$. t.d.s., Dartalan 10 mg. t.d.s.

CASE 2 A.E., a woman aged 35, was admitted on 17 April 1962. She has five sibs, three affected by the disease, and the mother had the disease. She is married with one son. The illness commenced in 1958. She has had episodes of depression and irresponsible behaviour, e.g., with money, and has worked as a model. Gradually the 
choreiform movements became intensified and now she can walk unaided but is unsteady; chorea is marked and speech slurred. She eats messily. She has lost $2 \frac{1}{2}$ stones in weight since the onset of the illness. She is on Dartalan $10 \mathrm{mg}$. t.d.s. and Tryptizol $25 \mathrm{mg}$. t.d.s.

Before beginning the trial the patients had been stabilized on Dartalan $10 \mathrm{mg}$. t.d.s. for at least three months and none of the medication was altered during the trial.

\section{DESIGN OF THE TRIAL}

The patients' condition was assessed before commencing penicillamine, and an attempt was made to rate the degree of disability on a scale as set out in Table I. A

\section{TABLE I}

METHOD OF ASSESSMENT OF DEGREE OF DISABLEMENT OF PATIENT

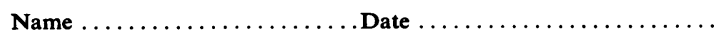

Weight...................

Item 1 Dexterity

(a) Copy circle on paper $\times 3$.

Score 5 each $=15$

graded 1 , perfect shape

2 , sound shape

3 , mild shakiness

4, severe shakiness

(b) Copy squares as above. Score 15

(c) Dot 'bull's eye' on paper with pencil from $1 \mathrm{ft}$. above table $\times$ 5. Max. score 15. $=$ total 45

Item 2 Conversation

Record on tape. Slurring and hesitancy noted. Scored $1-5$ by two independent observers. Total score 10.

Item 3 Gait

Graded 1, normal

2 , mild staggering

3 , severe staggering

4 , requires assistance to walk

5 , cannot stand unaided

Scored 1-5 by two independent observers $=10$.

N.B. Higher scores $=$ worse performance. Maximum total score $=65$.

tape recording was made to assess speech using set pieces of reading material, and the patients' gait and severity of chorea were rated. The patients' weight was noted. It was hoped in this way that these indices would provide an objective assessment of any improvement that might occur. A full blood count was performed and the urine tested for albumin. These were repeated fortnightly throughout the trial, since adverse side effects have been noted, e.g., nephrosis (Adams, Goldman, Maxwell, and Latta, 1964) and leucopenia and agranulocytosis (Corcos, Saler-Bechara, Mayer, Freyberg, Goldstein, and Jaffe, 1964 ; Conway and Walker, 1962) in patients with Wilson's disease on long-term treatment. The patients were also given pyridoxine $50 \mathrm{mg}$. daily throughout the trial since penicillamine has been noted to have an anti-pyridoxine effect in man (Jaffe, Altman, and Merryman, 1964).

The patients commenced penicillamine at a dose of $50 \mathrm{mg}$. t.d.s. and this was increased to $450 \mathrm{mg}$. t.d.s. over a two-week period and maintained at this level. At the end of six months the assessment described above was repeated.

RESULTS

A comparison of the scores before and after six months' treatment is shown in Table II.

TABLE II

RESULTS OF ASSESSMENTS IN PATIENTS (DETERIORATION INDEX)

\begin{tabular}{lllll}
$\begin{array}{l}\text { Possible } \\
\text { Score }\end{array}$ & \begin{tabular}{l} 
Before \\
\cline { 2 - 3 } \cline { 5 - 6 }
\end{tabular} & After Six Months \\
\hline Patient 1 Patient 2 & Patient 2 & & Patient \\
\hline
\end{tabular}

\begin{tabular}{lrrrrr}
\hline Item Ia & 15 & 8 & 7 & 15 & 7 \\
Ib & 15 & 7 & 9 & 13 & 7 \\
Ic & 15 & 5 & 6 & 13 & 5 \\
Item II & 10 & 6 & 6 & 8 & 4 \\
Item III & 10 & 6 & 4 & 10 & 4 \\
Total & 65 & 32 & 31 & 61 & 27 \\
$\begin{array}{l}\text { Weight } \\
\text { (st. Ib.) }\end{array}$ & & 93 & 77 & 713 & 812 \\
Weight & & & & & \\
$\begin{array}{l}\text { Change } \\
\text { (st. lb.) }\end{array}$ & & & & -14 & -15 \\
$\begin{array}{l}\text { Score } \\
\text { Alteration }\end{array}$ & & & & & \\
\end{tabular}

Magnesium levels in the cells and serum of both patients with Huntington's chorea and controb groups were all within normal limits (Tables III and IV). There was no statistical difference between the् two groups. The mean value of the erythrocyte $\frac{7}{8}$ magnesium levels for the Huntington's chorea group was $4.42 \mathrm{mEq}$./1. and for the controls $4.47 \mathrm{mEq} . / 1$. the mean of the packed cell volume (P.C.V.) for the two groups being identical at $41 \cdot 2 \%$.

The assessment of the patients on the trial of penicillamine shows that in the first patient deterioration had continued uninfluenced by the administration of a chelating agent. In the second patient there was a slight improvement over the six-month period but on the rating scale used this was not a significant change. However, the second patient did show a marked gain in weight (19 lb. in six months);

TABLE III

MEASUREMENTS IN PATIENTS WITH HUNTINGTON'S CHOREA

\begin{tabular}{ccccc}
$\begin{array}{l}\text { Patient } \\
\text { No. }\end{array}$ & $\begin{array}{l}\text { Plasma } \\
\text { Magnesium } \\
(\text { mEq./l. })\end{array}$ & $\begin{array}{l}\text { Whole Blood } \\
\text { Magnesium } \\
(\text { mEq./l. })\end{array}$ & $\begin{array}{l}\text { Red Cell } \\
\text { Magnesium } \\
(\text { mEq./l. })\end{array}$ & $\begin{array}{l}\text { P.C.V. } \\
(\%)\end{array}$ \\
\hline 1 & 1.9 & 2.9 & 4.5 & 43 \\
2 & 1.7 & 2.8 & 4.6 & 38 \\
3 & 1.7 & 2.8 & 4.3 & 43 \\
4 & 1.8 & 2.8 & 4.6 & 38 \\
5 & 1.8 & 2.7 & 3.9 & 43 \\
6 & 1.9 & 2.9 & 4.1 & 46 \\
7 & 1.6 & 2.7 & 4.0 & 46 \\
8 & 1.9 & 2.9 & 4.3 & 41 \\
9 & 1.7 & 2.9 & 4.8 & 39 \\
10 & 1.5 & 2.9 & 5.1 & 39 \\
Mean & 1.75 & 2.83 & 4.42 & 41.2
\end{tabular}


TABLE IV

\begin{tabular}{|c|c|c|c|c|}
\hline & MEASURE & NTS IN CONT & OL GROUP & \\
\hline $\begin{array}{l}\text { Patient } \\
\text { No. }\end{array}$ & $\begin{array}{l}\text { Plasma } \\
\text { Magnesium } \\
\text { (mEq./l.) }\end{array}$ & $\begin{array}{l}\text { Whole Blood } \\
\text { Magnesium } \\
\text { (mEq./l.) }\end{array}$ & $\begin{array}{l}\text { Red Cell } \\
\text { Magnesium } \\
\text { (mEq./l.) }\end{array}$ & $\begin{array}{l}\text { P.C.V. } \\
(\%)\end{array}$ \\
\hline 1 & 1.5 & $2 \cdot 5$ & $4 \cdot 2$ & 37 \\
\hline 2 & 1.7 & $3 \cdot 2$ & $5 \cdot 4$ & 41 \\
\hline 3 & 1.7 & $3 \cdot 2$ & 5.1 & 44 \\
\hline 4 & 1.8 & $2 \cdot 8$ & $4 \cdot 3$ & 40 \\
\hline 5 & 1.9 & $2 \cdot 7$ & $4 \cdot 0$ & 39 \\
\hline 6 & 1.5 & $2 \cdot 3$ & 3.6 & 38 \\
\hline 7 & 1.6 & 2.8 & $4 \cdot 3$ & 45 \\
\hline 8 & 1.8 & $2 \cdot 8$ & $4 \cdot 0$ & 45 \\
\hline 9 & 1.8 & 3.4 & $5 \cdot 6$ & 42 \\
\hline 10 & 1.5 & $2 \cdot 6$ & $4 \cdot 2$ & 41 \\
\hline Mean & 1.68 & $2 \cdot 83$ & 4.47 & $41 \cdot 2$ \\
\hline
\end{tabular}

her choreiform movements undoubtedly were less marked, and her mental state was improved. It is quite possible that the last improvement could be due to the increased attention and the element of hope engendered by new treatment. However, it was not noted in any of the other patients who were not on the drug, nor in the first patient who had in fact lost $18 \mathrm{lb}$.

\section{DISCUSSION}

The results of estimating intracellular magnesium levels in both the control groups and the group with Huntington's chorea showed no significant deviation from the normal level, all levels falling between $3.6 \mathrm{mEq}$./1. and $5.6 \mathrm{mEq}$./1., the mean being 4.42 $\mathrm{mEq}$./1. This confirms the findings of Bruyn et al. (1965) who found no abnormal magnesium levels in a group of patients with Huntington's chorea.

Penicillamine has been used in a number of conditions, chiefly associated with heavy metal poisoning. In view of the absence of abnormal magnesium levels any beneficial action that occurred could not be put down to this. In Wilson's disease the dose required has been found to vary between 600 and $4,000 \mathrm{mg}$./day, the average patient requiring $1,200 \mathrm{mg}$. daily to maintain them in negative copper balance. Treatment may need to go on for a year before much improvement is seen.

In cystinuria the rationale for the use of penicillamine is based upon the respective solubilities of cystine, cysteine, penicillamine, and their disulphides. However, cystinuric patients excrete less cysteine when given penicillamine whereas normal patients excrete 10 times more, and there must therefore be a further factor involved. Any action which is beneficial in Huntington's chorea must at this juncture remain speculative. It is known that $D$-penicillamine has metal-binding properties: it makes - $\mathrm{SH}$ bonds available in tissue enzyme systems. Penicillamine has also been shown to have growth-promoting proper- ties in the chick and pig (Taylor and Gordon, 1955) ${ }^{\circ}$ Twenty-four-hour urinary excretion of xanthurenic acid and kynurenine is increased. Penicillamine may act in part by supplying sulphydryl groups to replace those that may be blocked by copper in Wilson's disease. In Huntington's chorea there is presumably an enzymatic disturbance and it may well be that some enzyme systems are blocked and can be persuaded to function more efficiently by this activity. Penicillamine also has an immuno-suppressive effect (Tobin and Altman, 1964) and these workers suggest that these effects may be intracellular. There are thus a number of mechanisms whereby penicillamine might act.

Turning to the patients under treatment, the first patient had undoubtedly continued to deteriorate during the six months. His score on the scale was 32 before treatment and 61 after. He could not stand unassisted. He had lost a further $18 \mathrm{lb}$. in weight. The second patient, however, proved more promising. At the end of six months she had gained $19 \mathrm{lb}$. in weight and was certainly exhibiting less choreiform movement. The scale brought this out to some extent but proved unsatisfactory as a fine measure of improvement. Her speech was not markedly better. But the results seem promising enough to justify continuing treatment and widening the scope of the trial which it is now hoped to do, with a proper control. Nielsen and Butt's work with B.A.L. also showed promising results, but they had to discontinue treatment at the end of the year because the intramuscular injections proved too traumatic.

\section{SUMMARY}

A survey of patients with Huntington's chorea using atomic absorption spectroscopy showed no detectable abnormality of magnesium levels in cells or serum.

A pilot trial of penicillamine in the treatment of Huntington's chorea on two patients showed mild improvement in one after six months but deterioration continued unabated in the other. Possible mechanisms by which penicillamine might be operating are discussed.

I would like to thank Dr. J. P. Child for his support in this project, Dr. J. R. Roy and Dr. P. Morgan for permission to treat the patients under their care, and Dr. W. H. Lyle of Dista Products for his help and generosity in supplying penicillamine for the project: also to G. B. Pendlerton, senior biochemist at the Newcastle General Hospital, for his cooperation in estimating magnesium levels in the patients on the trial. 


\section{ADDENDUM}

At one year follow-up, patient 2, who had shown improvement, now has a rating score of 48 (a deterioration of 21 points) and his weight has dropped to $6 \mathrm{st}$. 6lb., a change of $-2 \mathrm{st}$. 6lb., following an episode of pneumonia. One must conclude, therefore, that penicillamine in this case has brought at best a temporary improvement only in the patient's condition.

\section{REFERENCES}

Adams, D. A., Goldman, R., Maxwell, M. H., and Latta, H. (1964). Nephrotic syndrome associated with penicillamine therapy of Wilson's disease. Amer. J. Med., 36, 330-336.

Baron, D. N., and Bell, G. L. (1957). Clin. Chim. Acta, 2, 327.

Bruyn, G. W., Mink, C. J. K., and Caljé, J. F. (1965). Biochemical studies in Huntington's chorea. Erythrocyte magnesium. Neurology (Minneap.), 15, 455-461.
Conway, N., and Walker, J. M. (1962). Treatment of macroglobinaemia. Brit. med. J., 2, 1296-1297.

Corcos, J. M., Soler-Bechara, J., Mayer, K., Freyberg, R. H., Goldstein, R., and Jaffe, I. (1964). Neutrophilic agranulocytosis during administration of penicillamine. J. Amer. med. Ass., 189, 265-268.

Jaffe, I. A., Altman, K., and Merryman, P. (1964). The antipyridoxine effect of penicillamine in man. J. clin. Invest., 43, 1869-1873.

Kenyon, F. E., and Hardy, S. M. (1963). A biochemical study of Huntington's chorea. J. Neurol. Neurosurg. Psychiat., 26, 123-126.

Mann, C. K., and Yoe, J. H. (1956). Spectrophotometric determination of magnesium with sodium 1-azo-2-hydroxy-3-(2,4dimethylcarboxanilido)-naphthalene-1'-(2-hydroxybenzene-5sulfonate). Analyt. Chem., 28, 202-205.

Nielsen, J. M., and Butt, E. M. (1955). Treatment of Huntington's chorea with BAL. Bull. Los Angeles neurol. Soc., 20, 38-39.

Taylor, J. H., and Gordon, W. S. (1955). Growth-promoting activity for pigs of inactivated penicillin. Nature (Lond.), 176, 312-313.

Tobin, M. A., and Altman, K. (1964). Accelerated immune response induced by D-L. penicillamine. Proc. Soc. exp. Biol. (N.Y.), 115, 225.

\section{The February 1967 Issue}

\section{THE FEBRUARY 1967 ISSUE CONTAINS THE FOLLOWING PAPERS}

Epidemiological study of multiple sclerosis in Israel Part III Multiple sclerosis and socio-economic status AARON ANTONOVSKY, URI LEIBOWITZ, JACK M. MEDALIE, HERBERT A. SMITH, LIPMAN HALPERN, and MILTON ALTER

Role of vitamin $B_{12}$ deficiency in tropical 'nutritional' neuromyelopathy K.N. JEEJEEBHOY, N. H. WADIA, and H. G. DESAI

Conservative treatment and natural history of acute lumbar disc lesions JOHN PEARCE and J. M. H. MOLL

Pressure neuropathy in the hind foot of the guinea-pig PAMELA M. FULLERTON and R. W. GILLIATT

On the pattern of change in peripheral nerves produced by isoniazid intoxication in rats J. B. CAVANAGH

Effect of the Jendrassik manoeuvre on a phasic stretch in normal human subjects during experimental control over supraspinal influences ALEX M. CLARKE

Immunoelectrophoretic investigations of blood serum proteins in muscular diseases WALERIA ASKANAS

Myotonic lid lag in hypokalaemic periodic paralysis JEROME S. RESNICK and W. KING ENGEL
Creatine phosphokinase in the cerebrospinal fluid MARTIN J. NATHAN

Addison's disease and diffuse cerebral sclerosis HOEFNAGEL, A. BRUN, S. H. INGBAR, and H. GOLDMAN

Pseudo-aneurysms in relationship to massive cerebral haemorrhage F. M. COLE and P. O. YATES

Clinical presentation of ruptured intracranial aneurysm MARTIN SARNER and F. CLIFFORD ROSE

Neurofibromatosis with congenital malformation of the spinal cord A. J. BARSON and F. M. COLE

Sudanophil leucodystrophy: a study of intersib variation in the form taken by the demyelinating process $R$. M. NORMAN, the late A. H. TINGEY, J. C. VALENTINE, and H. J. HISLOP

Proceedings of the Society of British Neurological Surgeons

Book reviews

Copies are still available and may be obtained from the PUBLISHING MANAGER, BRITISH MEDICAL ASSOCIATION, TAVISTOCK SQUARE, W. c. 1., price 18s. 6D. 